\title{
Comparative Analysis of International Competitiveness of Chinese - American Automobile Industry
}

\author{
Xinying Liu ${ }^{1, a}$, Shenyingjie Zhang ${ }^{2, b}$, Xueyao Feng ${ }^{3, c}$ \\ ${ }^{1}$ Department of International Economics and Trade, Shandong University of Finance and \\ Economics, Jinan, Shandong Province, 250014,China \\ ${ }^{2}$ Department of International Economics and Trade, Shandong University of Finance and \\ Economics, Jinan, Shandong Province, 250014,China \\ ${ }^{3}$ Department of International Economics and Trade, Shandong University of Finance and \\ Economics, Jinan, Shandong Province, 250014,China \\ aemail:
} sheila_guo1988@hotmail.com, bemail:zhangshenyingjie@163.com, 'email:fengxy1993@126.com

Keywords: Chinese-American Automobile Industry; Analysis of international competitiveness; Michael Porter diamond Model

\begin{abstract}
Along with the repaid development of the transportation industry and the demand of the residents, the automobile industry has gradually developed into a pillar industry of the national industry. The level of a country's automobile industry development can also reflect the overall level of the country's manufacturing industry. Automobile industry is known as a capital-intensive and technology-intensive industries whose high input and output can pull the development of steel, chemicals, machine tools and other upstream industries. Considering the differences of China and American in the nature of the country and the industrial basis, there are lots of differences in the development of Chinese and American automobile industry. Therefore, a comparative study of the international competitiveness of Chinese and American automobile industry is of great significance. Under the Porter's diamond theory, this paper is divided into nine parts which systematically analysis the differences. Such as resource elements, demand conditions, related industries, business strategies, structure and competitors, policies and opportunities and so on. Then we put forward reasonable and effective recommendations on the development of Chinese auto companies.
\end{abstract}

\section{Introduction}

In the year of 2014, the number of the output in Chinese automobile is 23,499,001 and the number in 2015 is $24,597,583$ which had an increase of $4.68 \%$. And the proportion of total output in the world is $27.43 \%$. From the data, we can conclude that Chinese automobile industry developed rapidly. However, it is widely acknowledged that Chinese automobile industrial international competitiveness still has many disadvantages. For example, the technological level is lower than other developed countries. Therefore, it is vital to analysis international competitiveness of Chinese automobile industry. In the meantime, American automobile industry has lots of advantages. This paper aimed to compare the differences of Chinese and American international competitiveness of automobile industrial through the Porter's diamond theory.

\section{Related theories and concepts}

\section{The International Competitiveness}

Different economic organizations have different definitions of international competitiveness. At present, the world has not formed a recognized concept of authority for international competitiveness.

This paper hold that the international competitiveness is defined the ability to provide products or services for meeting the needs of domestic and foreign markets in order to make profits. 


\section{Michael Porter Diamond Model}

Professor Michael Porter (1990) puts forward a dynamic model of international competitiveness, explains why some industries in a country will have strong competitiveness in the international market, and summed up the six factors that can affect the competitiveness of a country's industry, namely, factors of production, Demand conditions, related and supporting industries, corporate strategy, market structure and competitors, governments and opportunities, which is the Porter diamond model shown in Fig.1. This paper is to use Porter's diamond theory model to compare the international competitiveness of China-US auto industry from six aspects.

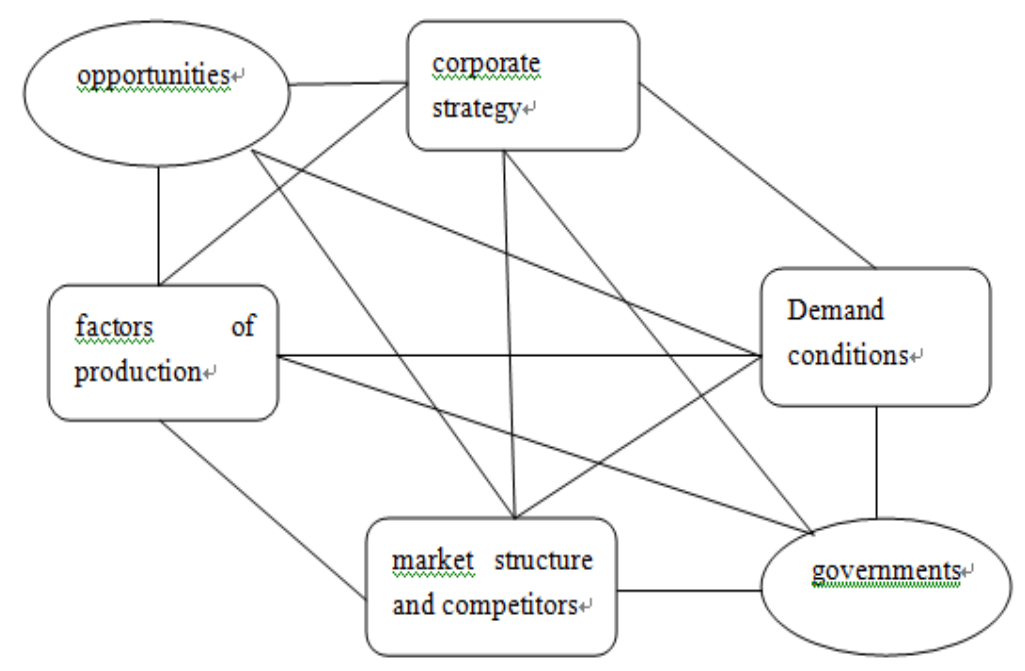

Fig.1. Michael Porter diamond Model

\section{Comparison of Domestic Determinants}

\section{Comparison of Resource Factors between Chinese and American Automobile}

Porter divides elements into two categories: basic elements and advanced elements. Among them, the former has a more important role in competitive advantage. Since the 1980s, although Technology occupies an important position in auto industry the labor force still occupies an important position which can't be shaked.

In 2008, the wages of auto workers in mainland China was 13.58RMB per hour, while the wages of American auto workers was 498.59RMB per hour, almost 36 times the salary of auto workers in mainland China, showing the gap between China and the United States labor costs. One reason is that China has a large population and unlimited labor supply. The second reason is that the Chinese Workers 'Federation and the Workers' Union of the Capitalist Countries are of a different nature. According to expert estimates, China's labor advantage will continue for 10 to 20 years.

According to Morgan JP released report shows that in the past 15 years the U.S. General Motors the burden of working and retired employees of the medical expenses and payment of the retired staff salaries of $\$ 103$ billion, affected by the high labor expenses, GM annual investment in infrastructure construction accounted for only $8.7 \%$ of the proportion of their income. Other international well-known automobile manufacturing enterprises in the investment is generally about $14 \%$. If labor costs will be added to the single car, that every American car on the U.S. auto workers labor costs more than $\$ 1000$. The higher labor costs of the U. S. auto manufacturing reduced the profit space. At the same time, protecting the environment will make the United Auto Workers go slow, the automobile production in the United States caused a very bad effect.

At the same time, the American automobile manufacturing industry started earlier, and the research and development investment is higher. As can be seen from the Table.1 the U.S. General Motors and Ford motors were 550 thousand and 420 thousand of R \& D investment ranked twelfth and twenty-third while there is no Chinese automobile manufacturing enterprises. 
Table.1. 2013 Enterprise’s R\&D investment Ranking

\begin{tabular}{|l|l|l|}
\hline Enterprise name & Ranking & R\&D investment (Billion Euros) \\
\hline Volkswagen & 1 & 95 \\
\hline Toyota Motor Corporation & 5 & 71 \\
\hline Daimler & 11 & 56 \\
\hline $\begin{array}{l}\text { General Motors } \\
\text { Corporation }\end{array}$ & 12 & 55 \\
\hline HONDA & 16 & 49 \\
\hline Ford Motor Company & 23 & 42 \\
\hline NISSAN & 25 & 41 \\
\hline
\end{tabular}

\section{Demand comparison of Chinese and American in auto industry}

Due to the imbalance of China's regional economic development, there are a large number of low-end consumer groups in three, two tier cities in mainland China, which occupy most of the car sales market. So the price is in the primary factor in consumer consideration in China's auto market considering lower revenue of customs.

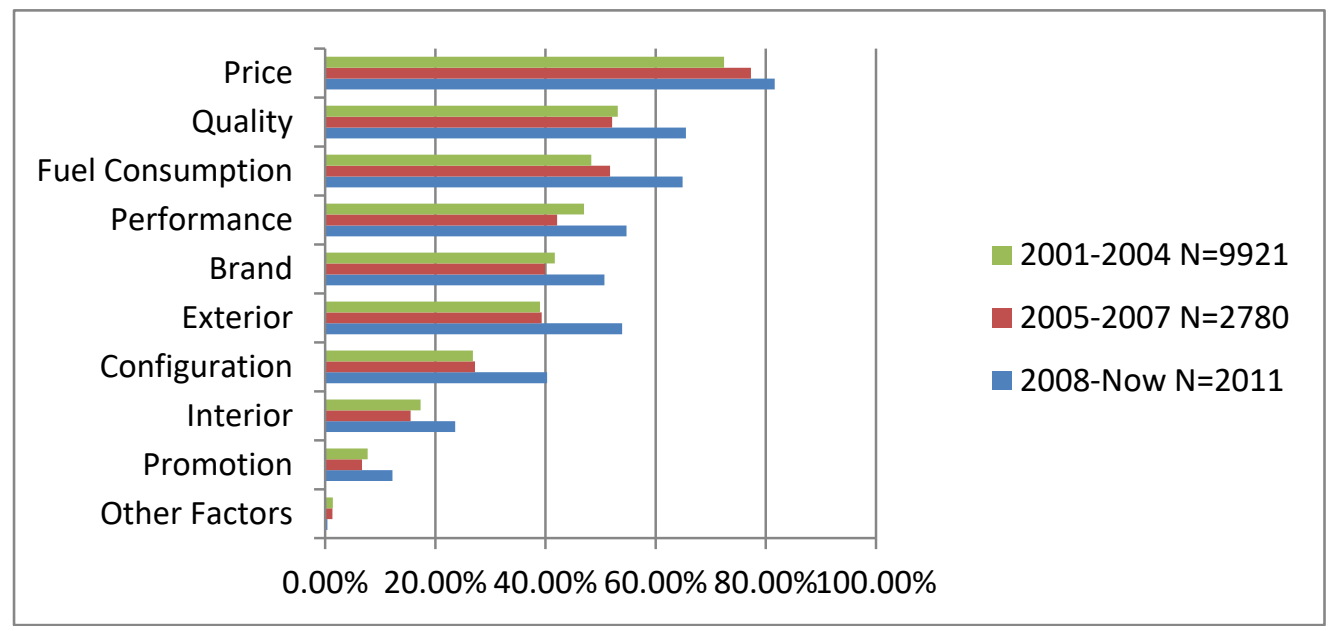

Fig.2. Reference Factors of Car buyers

Not difficult to see from the Fig.2 in 2007 it had more than $70 \%$ of the respondents who thought that when the car price was the main factor to decide buy a car. After 2008 the proportion rose to $80 \%$. Compared with a few years ago, in recent years, consumers in Car Buying will be quality, fuel consumption and appearance as a reference factor, but the price is still the most important factor for consumers.

According to the survey results published in the American Journal of consumer reports, the primary reference factors most American consumers consider the purchase of a car's fuel consumption. Among those surveyed, $27 \%$ said in the car purchase value in fuel consumption, followed by $25 \%$ of said value car reliability in the car purchase, in addition to $14 \%$ and $12 \%$ the respondents value the price and car safety performance.

Among this, we can conclude that American has an advantage in technical as well as in demand when considering customs' revenue.

\section{Comparison of external influence factors}

From the current situation, Chinese automobile enterprise's scale is still small while the technical level is relatively weak. So it has not formed the scale benefits. The numbers of production of Chinese car are the most in the world, but nearly $60 \%$ of the yield from foreign companies. In recent years, Chinese automobile market competition is fierce: on the first 2 months of 2014, Chinese passenger car sales grew by 13\% over the same period in 2013. By the end of 2014 and in May sales in the domestic car market share fell to 38\%, lower than the same period last year nearly $42 \%$.

However, the U.S. auto manufacturing industry started earlier and it has formed a scale advantage. In 2003, the three U.S. auto giant proportion in its domestic market sales amounted to approximately $59.4 \%$ of its sales in 2009 , the proportion dropped to $43.66 \%$, while the Japanese car 
TOYOTA, Honda and Nissan constantly narrow the gap and the competition of the industry. The South Korean cars into the U.S. market recently.

\section{Conclusion}

Table.2. Comparative Analysis of International Competitiveness of Chinese - American Automobile Industry

\begin{tabular}{|c|c|c|c|}
\hline Factors & China & United States & Comparison conclusion \\
\hline $\begin{array}{l}\text { Factors of } \\
\text { production }\end{array}$ & low labor cost & high labor cost & China has advantage \\
\hline $\begin{array}{c}\text { Demand } \\
\text { Conditions }\end{array}$ & $\begin{array}{l}\text { consumers are only concerned } \\
\text { about the price }\end{array}$ & $\begin{array}{c}\text { consumers are concerned } \\
\text { about the fuel consumption、 } \\
\text { safety performance etc. }\end{array}$ & US has advantage \\
\hline $\begin{array}{l}\text { Related and } \\
\text { Supporting } \\
\text { Industries }\end{array}$ & $\begin{array}{l}\text { low integration of auxiliary } \\
\text { industry }\end{array}$ & $\begin{array}{l}\text { high integration of auxiliary } \\
\text { industry }\end{array}$ & US has advantage \\
\hline $\begin{array}{l}\text { Corporate } \\
\text { Strategy }\end{array}$ & Consumer-oriented & profit-oriented & China has advantage \\
\hline $\begin{array}{l}\text { Market Structure } \\
\text { and Competitors }\end{array}$ & $\begin{array}{c}\text { Car firms haven’t achieve } \\
\text { economies of scale.China has } \\
\text { big emerging market . }\end{array}$ & $\begin{array}{l}\text { Automobile Industry have } \\
\text { achieved economies of scale, } \\
\text { almost fulfill mature market . }\end{array}$ & China has advantage \\
\hline $\begin{array}{l}\text { Governments and } \\
\text { Opportunities }\end{array}$ & $\begin{array}{l}\text { Policies help to protect energy } \\
\text { and environment or govern } \\
\text { automotive market }\end{array}$ & $\begin{array}{l}\text { Policies help to protect } \\
\text { energy and environment or } \\
\text { govern automotive market }\end{array}$ & $\begin{array}{l}\text { China and US both have } \\
\text { advantage }\end{array}$ \\
\hline
\end{tabular}

According to Potter's diamond model and the information from Table.2, we believe that Chinese auto industry has more international competitiveness than the American automobile industry in the contemporary society.

There are some reasons: First, Chinese automobile manufacturing industry has a large number of cheap labor resources, making the cost of the automobile is low, so that the automobile production have the advantage of price. Second, Chinese corporate strategy is consumer-oriented, the production has more flexibility, and more able to cater to the consumer preference. Third, China has big new emerging market, Chinese population and consumer's demand is far from saturation. Fierce competition between enterprises in this competitive environment can make Chinese car manufacturers constantly adjusting strategy and developing technology. In order to avoid being out of the market. Fourth, Chinese government issued a new policy in recent years, in order to promote the reform and development of the automobile industry. Benefit from this policies the Chinese and foreign automobile manufacturing enterprises on the same starting line.

\section{Suggestions on improving the international competitiveness of Chinese automobile manufacturing industry}

\section{For enterprise}

First, the enterprises should try to create their own brand name in order to shape brand value. Second, the enterprises should accelerate the development of automobile service industry. Such as automotive financial services, insurance services. Try to increase the type of service and improve service's quality.

\section{For government}

Government can formulate relevant policies and regulations to promote the adjustment of industrial structure and realize powerful alliances. On the other hand, managers can optimize the industrial structure to achieve economies of scale.

\section{Acknowledgement}

In this paper, the research was sponsored by the brand courses of studying English in China in 
the year of 2013.

\section{References}

[1] Yang Zhi,Deng Yixuan. Comparative of International Competitiveness of Chinese and American Automobile Industry [J]. Journal of Theoretical, 9 (2011) 150-154.

[2] Wang Jing. Comparative of development differentiation of Chinese and American Automobile Industry [D]. Beijing:Capital University of Economics and Business, (2010) 14-16 33-36.

[3] Dai Wei. Comparative of International Competitiveness of Chinese and Korean Automobile Industry [D]. Hunan:Hunan University, (2012) 2-6.

[4] Yang Rudai, Zhu Shie. Analysis of the Structure and Competitiveness of Chinese Foreign Trade (1978-2006) [J]. Finance and Trade Economics, 2 (2008) 174.

[5] Wang Ji. What's wrong with American cars [M]. Beijing:China Machine Press (2009)

[6] Qian Zhenwei. Chinese Automobile Industry in the 21st [M]. Beijing:Beijing Institute of Technology Press (2004)

[7] Alfred Sloan. My Life in General Motors: Sloan’s Biography [M]. Beijing: Huaxia Press (2005)

[8] Xu Yang, SWOT Analysis of International Competitiveness of Chinese Own Brand Automobile Industry [J]. Chinese Business and Trade, 9 (2011) 194-195.

[9] Porter,M.The Competitive Advantage of Nations, [M]. Macmillan, London (1990) 